DRISTIKON, VOL. 11(1), 284-295, 2021, RMC, MMC, DHARAN

\title{
इस्मालीको बाटो कथामा प्रतिनिधित्व र पहिचान
}

\author{
सीता अधिकारी थापा \\ उपप्राध्यापक \\ नेपाली विभाग, महेन्द्र बहुमुखी क्याम्पस, धरान, त्रिभुवन विश्वविद्यालय, नेपाल \\ adhikari.sitath@gmail.com
}

DOI: https://doi.org/10.3126/dristikon.v11i1.39170

\section{लेखसार}

प्रस्तुत अध्ययनमा कथाकार इस्मालीद्वारा रचित बाटो कथाको प्रतिनिधित्व तथा पहिचानका आधारमा अध्ययन गरिएको छ। सांस्कृतिक अध्ययनका विविध अवधारणामध्ये यसमा स्टुआर्ट हलको प्रतिनिधित्व र पहिचानसम्बन्धी मान्यतालाई सैद्धान्तिक आधार लिइएको छ। व्यञ्जनामूलक अर्थ बहन गर्ने यस कथामा नेपालको तराई क्षेत्रको भौगोलिक परिवेशको सामाजिक सांस्कृतिक संरचनामा युगौंदेखि एकाधिकार जमाउँदे आएको सामन्ती संस्कृतिको जमिन्दारी प्रथाका अवशेष मालिकहरूले निम्न वर्गका समुदायलाई प्रयोग गरेर आफ्नो प्रभुत्व कायम गर्दे मच्चाउने वितण्डाबाट ग्रसित सामाजिक मनोदशाको सटिक चित्रण छ। परम्परावादी सामाजिक, सामन्तवादी सांस्कृतिक संरचनाका अवयवहरूमा विद्यमान दमनकारी सोच तथा अमानवीय प्रवृत्तिहरू परिवर्तित व्यवस्थामा पनि नेतृत्वका चरित्र र व्यवहारमा पुनरावृत्ति भइरहनु अत्यन्त नकारात्मक पक्ष हो। प्रतिगामी सत्ताशक्तिको आडमा दमनकारी विचारधाराका माध्यमबाट सीमान्तकृत बनाइएका बहुसड्ख्यक अधीनस्थ समुदायमाथिको उत्पीडनले परिवर्तनकामी प्रतिरोधी चेतनालाई दबाउन नसकिने यथार्थको उद्बोधन यसकथामार्फत प्रकटित भएको छा यस सन्दर्भमा रचिएको कथामा पुरानो व्यवस्थाको सामन्ती प्रवृत्तिको धङ्धडी र नयाँ व्यवस्थाको सुरूवात्को सङ्क्रमणकालीन परिवेशमा वर्गीय, जातीय, लैड़िक प्रतिनिधित्व, प्रभुत्व र विचारधाराको दून्दूको सशक्त प्रस्तुति रहेको छ। प्रतिनिधित्व र पहिचानले विकास गर्ने वर्गीय सड्घर्षको स्वरूप र चेतनाद्वारा प्रतिरोधको नवीन संज्ञानको निर्माण कसरी गरिएको छ भन्ने कृतिकेन्द्री आधारमा विश्लेषण गर्नु यस सांस्कृतिक अध्ययनको प्रमुख उद्देश्य रहेको छ।

शब्दकुज्जी : बहुसांस्कृतिकता, प्रतिनिधित्व, विचारधारा, पहिचान, वर्चस्व, वर्गीय चेतना, शक्तिसम्बन्ध

\section{विषय परिचय}

नेपाली आख्यान साहित्यका चिरपरिचित कथाकार इस्माली (महेश्वरप्रसाद उपाध्याय,२०१२) को प्रसिद्ध कथा हो- बाटो। नेपालको तराई क्षेत्रको स्थानीय जनजीवनको सामाजिक, आर्थिक एवम् सांस्कृतिक पाटोलाई यस कथाले जीवन्त अभिव्यक्ति दिएको छ। प्रगतिवादी यथार्थवादी साहित्यकार इस्मालीले आ0 ना रचनाकृतिमा समाजका अनेकौं सूक्ष्म घटना सन्दर्भका विषयवस्तुलाई चोटिलो रूपमा प्रस्तुत गरेका छन्। महेश पौडेलका नामबाट बाल साहित्य सिर्जनामा सक्रिय साहित्यकारका रूपमा समेत परिचित उनका सेतो आतङ्क (२०३९), जिरोमाइल (२०४६), दुर्धर्ष ( २०७३)औपन्यासिक कृति तथा माछो माछो भ्यागुतो (२०४२), घाम घामजस्तो छैन (२०४६), काट् डी जर्किन (२०६४), 
इस्मालीका प्रतिनिधि कथाहरू (२०६७), श्रीको खोजी (२०७३)आदि कथाकतिहरू प्रकाशित छन् । युरेसियाका कथा ( २०७३), बंगाली लेखिका महाश्वेतादेवीको उपन्यास 'अक्लान्त कौरव' जस्ता आख्यान कृतिका अनुवादक इस्मालीले सदैव सत्ता इत्तर वर्गका जनपक्षीय लेखकका रूपमा आफ्नो लेखनीलाई निरन्तरता दिएका छन्। उनका रचनाकृतिले विशेषत: नेपाली समाजका सामाजिक, आर्थिक, राजनीतिक, सांस्कृतिक वर्गीय अवस्थाका विभिन्न घटना सन्दर्भलाई साहित्यिक अभिव्यक्ति दिएका छन्। विभिन्न कारणबाट सीमान्तीय बनेका किनारीकृत वर्गका समसामयिक समस्याहरूको उठानका साथै तिनमा प्रस्तुत चेतनाको दर्बिलो आवाज नै इस्मालीका कथागत प्राप्ति मानिन्छन्।

सामाजिक विषयवस्तुमा रचित कथा 'बाटो' शीर्ष शब्दले अभिधात्मक अर्थ मूर्त रूपमा मानिस हिड्ने बाटो, यात्राको गन्तव्यतिर डोचाउने गोरेटो वा सडकको अर्थ प्रदान गर्दछ भने अमूर्त रूपमा मानव जीवनको गन्तब्यको मार्ग, पद्धति, तरिका तथा मानवीय चिन्तनको शैली/डोरेटो पनि हो । वि.सं. २०४६ को आन्दोलनपछि नेपालले प्राप्त गरेको राजनीतिक परिवर्तन तथा प्रजातन्त्र पुनः बहालीपछि, समाजको तल्लो तहको चेतनास्तरमा आउन थालेको परिवर्तन र चेतनाका भिल्काले जनमानसलाई बाटो निर्देशित गर्ने कामको आरम्भ पनि भयो। कथामा त्यस बाटोका माध्यमबाट नेपालको तराईका ग्रामीण समाजका विपन्न दमित, शोषित-पीडित सीमान्त बँधुवा मजदुरका रूपमा युगौंदेखि प्रताडित समुदायलाई गुलामीबाट आजादीको यात्रामा अघि बढ्न प्रेरित गरी गन्तव्यमा पुच्याउनु पर्ने स्वतन्त्रताको अर्थ प्रतिपादन गरिएको छ। यस्तै सामाजिक संस्कृतिको पृष्ठभूमि र सन्दर्भमा लेखिएको प्रस्तुत बाटो कथाले परिवर्तनकामी चेतनाबाट देशका गाउँ सहर, हिमाल, पहाडजस्तै तराइको समाज पनि ऋमशः प्रभावित बन्दै गएको तथ्य कथाको कथ्यबाट प्रष्टिन्छ। सीमान्तकृत पारिएका मानिसले पुरानै सामन्तवादी यथास्थितिवादी शोषणमै रहने वा अग्रगामी परिवर्तनतिर जाने हो ? भन्ने आशयमा कथाले अबको समाज र निम्न वर्गीय समुदायको जीवनस्तर परिवर्तनको लागि दिशानिर्देश गर्ने अगाडिको बाटो के कस्तो हुने हो भन्ने सड्केतात्मक अर्थ अभिव्यज्जित गरेको छ। यस 'बाटो' कथालाई यहाँ प्रतिनिधित्व र पहिचानको पक्षबाट अध्ययन विश्लेषण गरिएको छ ।

साहित्य समालोचनाको क्षेत्रमा सांस्कृतिक अध्ययन उत्तरआधुनिकतावादी बहुलवादी चरित्रबाट अभिप्रेरित रहेको विभिन्न वैचारिक सिद्धान्तहरूको लोकप्रिय समालोचना क्षेत्र हो। माक्क्सवादको वर्ग र वर्गसड्घर्षवाट प्रभावित हुँदाहुँदे पनि त्यसबाट केही भिन्न धारको चेतनाद्वारा अभिप्रेरित भई मूलतः बेलायती नवमार्क्सवादीहरूबाट सांस्कृतिक अध्ययनको आरम्भ गरिएको हो र यस अवधारणाले साहित्यिक रचनाको विविध पक्षबाट विश्लेषण गर्दछ। क्रिस वाकरले सांस्कृतिक अध्ययन प्रतिस्पर्धी प्राप्त्याशाहरूको त्यो बहुल क्षेत्र हो जसले सिद्धान्तहरूको उत्पादनमार्फत् सांस्कृतिक राजनीतिमाथि श्रेष्ठताको आधारमा हस्तक्षेप बढाउने काम गर्दछ र सामाजिक सत्ता (पावर) को सन्दर्भभित्र प्रतिनिधित्वका सङ्केतीकृत व्यवहारहरूका रूपमा संस्कृतिको विश्लेषण गर्दछ (चैतन्य, २०७० : १६१)। मिश्रित चरित्रको यस अध्ययनमा समाजको शक्तिसम्बन्धका आधारहरू, वर्चस्व, वर्गीय, जातीय, लैड़िक पहिचान र प्रतिनिधित्वका साथै नारीवाद, जनजाति, राष्ट्रियता लगायतका सांस्कृतिकताका अन्य धेरै पक्षलाई अध्ययनको क्षेत्रका रूपमा स्वीकारिएको छ। यस लेखमा नेपाली आख्यानका इस्मालीद्वारा रचित बाटो कथाको प्रतिनिधित्व, पहिचान र प्रभुत्व/सत्तासम्बन्धका सांस्कृतिक आधारमा विश्लेषण गर्दे यसभित्र सामन्ती विचारधाराको प्रभुत्वका विरूद्ध विकसित हुन थालेको नवचेतनाको बाटोको सङ्केत किटान गरिएको छ। 


\section{समस्याकथन}

प्रस्तुत आलेखमा कथाकार इस्मालीद्वारा रचित बाटो कथाको प्रतिनिधित्व र पहिचानको अध्ययन प्रमुख समस्या हो भने यसैलाई आधार बनाएर कथाभित्रका निम्न शोध्य प्रश्नहरूमा केन्द्रित भई सांस्कृतिक विश्लेषण गरिएको छ :

- इस्मालीको बाटो कथाको पृष्ठभूमिगत सन्दर्भ के रहेको छ?

- बाटो कथामा प्रतिनिधित्व र पहिचानका मूलभूत सङ्केतहरू कसरी प्रयोग भएका छन् ?

- अर्थ उत्पादनमा प्रतिनिधित्व र पहिचानको भूमिका किन महत्त्वपूर्ण हुन्छ ?

\section{उद्देश्य}

उपर्युक्त समस्या कथनमा प्रस्तुत गरिएका शोध्य प्रश्नहरूको समाधान बाटो कथाको पाठमा केन्द्रित भएर खोज्ने यसअध्ययनको उद्देश्य निम्नानुसार रहेको छ :

- इस्मालीको बाटो कथाको पृष्ठभूमिगत सन्दर्भको समीक्षा गर्नु

- इस्मालीकृत बाटो कथामा प्रयुक्त सांस्कृतिक प्रतिनिधित्व र पहिचानका सङ्केतहरूको विवेचना गर्नु,

- अर्थ उत्पादनमा प्रतिनिधित्व र पहिचानको भूमिकाको मूल्याङ्कन गर्नु ।

\section{शोधविधि तथा सामग्री}

प्रस्तुत लेखका लागि अत्यावश्यक सामग्री सड्कलन तथा अध्ययनका ऋममा मूलतः पुस्तकालयीय स्रोतको उपयोग गरिएको छ। यसबाट उपलब्ध सामग्रीमा कथाकार इस्मालीको बाटो कथालाई प्रमुख अध्ययन सामग्रीका रूपमा लिइएको छ भने सांस्कृतिक अध्ययनसम्बन्धी अन्य प्रतिनिधित्व र पहिचानका विविध सैद्धान्तिक अवधारणा तथा पुस्तक, पत्रपत्रिका आदिलाई द्वितीयक स्रोत सामग्रीका रूपमा उपयोग गरिएको छ। त्यसैगरी विषयवस्तुलाई वेलायती सांस्कृतिक अध्येता स्टुआर्ट हलको सांस्कृतिक अध्ययनको प्रतिनिधित्व र पहिचानसम्बन्धी सैद्धान्तिक पर्याधारमा रहेर गुणात्मक अध्ययन पद्धतिको प्रयोग गर्दे पाठकेन्द्री व्याख्यात्मक र विश्लेषणात्मक ढाँचाबाट अध्ययनको निष्कर्ष निकालिएको छ।

\section{अध्ययनको सीमा}

नेपाली साहित्यको आख्यान विधाका सशक्त प्रगतिवादी कथाकार इस्मालीका रचनाकृतिहरू सान्दर्भिक र समसामयिक विशेष महत्त्वका रहेका छन्। तिनीहरूको विभिन्न कोणबाट अध्ययन विश्लेषण हुनु अत्यावश्यक छ तापनि यस लेखमा कथाकारको बाटो कथालाई सांस्कृतिक अध्ययनको प्रतिनिधित्व तथा पहिचानका सैद्धान्तिक दृष्टिबाट विश्लेषण गरी निष्कर्ष निकाल्नु यस अध्ययनको सीमा रहेको छ।

\section{परिणाम तथा छलफल}

\section{सैद्धान्तिक पर्याधार :सांस्कृतिक अध्ययन}


सांस्कृतिक अध्ययनमा प्रयुक्त हुने प्रमुख पक्षहरू प्रतिनिधित्व, पहिचान, सत्ताशक्ति, प्रभुत्व, विमर्श आदि हुन् । स्टुआर्ट हलले प्रतिनिधित्वलाई भाषाका माध्यमबाट गरिने अर्थको उत्पादन (गिरी, २०७० : पृ. २६)का रूपमा व्याख्या गरेका छन् । प्रतिनिधि भनेको सामाजिक रूपमा स्वतन्त्र हैसियत राख्ने कुनै पनि व्यक्ति, वर्ग, समुदाय वा समूह हो, यसको सम्बन्ध सामाजिक, सांस्कृतिक राजनीतिक सत्ता, प्रभुत्व र पहिचानसँग रहेको मानिन्छ। प्रतिनिधित्वको अभ्यासको बोध सांस्कृतिक अध्ययनको मुख्य विषय पनि हो। समाजको संरचना कसरी भएको छ भन्ने प्रतिनिधित्वको केन्द्रीय प्रश्न हो भन्ने क्रिस वाकरको मान्यता रहेको छ (भट्टराई, २०७० : पृ.३३६)। त्यस्तै पहिचान भनेको आ० नो स्वत्व जुन व्यक्ति तथा वर्ग समुदायसँग सम्बन्धित सांस्कृतिक कुरा हो तापनि यसको राजनीतिसँग प्रत्यक्ष सम्बन्ध रहेको हुन्छ। सांस्कृतिक अध्ययनमा प्रमुख महत्त्व राख्ने सत्ता र यसको वर्चस्व पनि हो जसको सम्बन्ध बल र विचारधारासँग रहेको मानिन्छ। एडगर र सेडविक, २००४ : ३०४ का अनुसार सामान्यतः सत्ता कुनै व्यक्ति वा समूहलाई अर्को व्यक्ति वा समूहमाथि बल प्रयोग गर्ने वा नियन्त्रण गर्ने माध्यम हो (भट्टराई, पृ. ३३६)। सत्ताको प्रत्यक्ष सम्बन्ध बल प्रयोग गरेर मात्र नभई यसले अन्य विभिन्न साधनहरूको निर्माण गरी त्यसका माध्यमबाट सहमतिमा आ0 नो सत्ताको संरक्षण पनि गर्दछ। समाज राजनीतिक संरचनामा एक वर्गले अर्को वर्गमाथि दमन वा नियन्त्रण गर्न विभिन्न नियम कानुन, संस्कृति साहित्य आदिको उपकरण रचना गर्दछ।

प्रतिनिधित्व र पहिचानलाई मार्क्सवादी र नवमार्क्सवादीहरूले अलग रूपमा व्याख्या विश्लेषण गरेका छन्। मार्क्सवादले सत्ताको सम्बन्ध वर्गीय रूपमा व्याख्या गर्दे सत्ता वर्ग शोषणको माध्यम पनि भएकाले वर्गसड्घर्षको माध्यमबाट सत्ता परिवर्तन हुने मान्यता राखेको पाइन्छ। सांस्कृतिक अध्ययनका सन्दर्भमा प्रतिनिधित्वको तात्पर्य एक प्रकारका सङ्केतपरक अभ्यासहरूको प्रतिनिधित्व र त्यसको बोध हो जुन पाठ, सामाजिक प्रक्रिया, सङ्कथन, विचारधारा, संस्थाहरू र अर्थतत्त्रका आधारमा गरिन्छ (भट्टराई, पृ. ३३६)। साहित्यमा पात्रगत आधारमा लैड्गिक, वर्गीय, जातीय, क्षेत्रीय आदिका साथै विचारधारात्मक प्रतिनिधित्व हुने भएकाले त्यसकै माध्यमबाट पहिचान पनि स्थापित भएको हुन्छ। सांस्कृतिक अध्ययनमा भाषामार्फत अर्थको उत्पादन गर्नु नै प्रतिनिधित्वको अर्थ हो भन्ने स्टुआर्ट हलले प्रतिनिधित्वका पनि प्रतिविम्बात्मक, अभिप्रायमूलक र संरचनात्मक गरी तीन सिद्धान्त प्रस्तुत गरेका छन् (चैतन्य, २०७० : पृ. १५९)। प्रतिबिम्बात्मक सिद्धान्तअनुसार अर्थ भनेको यथार्थ विश्वका कुनै व्यक्ति, वस्तु, घटना अथवा विचारका माध्यमबाट अभिव्यक्त चिन्तन र भाषिक क्रियाकलापद्वारा प्रतिनिधित्व गर्दछ भने अभिप्रायमूलक सिद्धान्त भनेको कुनै व्यक्तिद्वारा भाषामार्फत आ0 ना विचार/भावलाई संप्रेषित गर्नु हो र संरचनावादी सिद्धान्तका अनुसार अवधारणाहरू र चिन्हहरूको उपयोग गरी अर्थको रचना गरिन्छ। सत्ताको उत्तर संरचनावादी व्याख्याता फ्रान्सेली प्रमुख चिन्तक दार्शनिक मिसेल फुकोको विचारमा सत्ताको निर्माण सामाजिक कार्य, सम्बन्ध वा आदेशबाट हुन्छ। यस्तो सत्ता निर्माणमा सड्कथन शक्तिको भूमिका महत्त्वपूर्ण रहन्छ। फुकोका दृष्टिमा सत्ताको सम्बन्ध दमन, निषेध वा प्रत्यक्ष नियन्त्रणसंग मात्र नभई संस्थागतता तथा परम्परामा प्रचलित सड्कथनहरूबाट हुन्छ जसले कार्य, ज्ञान र सत्ताका असीमित स्वरूपहरू खुला गर्दछ (ब्रुकर, १९९९ : पृ. १७७)। संस्थागत रूपमा तयार पारिएका सङ्कथनहरूलाई आधिकारिक र वैध रूपमा परिभाषित गरेर यिनीहरूको अस्तित्वलाई संस्थागत रूपमै स्वीकार्न बाध्य पारिएको हुन्छ भन्दे फुकोले सत्ताको निर्माणमा भाषाको अहम् भूमिका रहने बताएका छन्। यिनै सत्ता, शक्ति, वर्चस्व एवम् प्रतिनिधित्वका विविध आधारमा बाटो कथालाई हेर्न सकिन्छ। 


\section{बाटो कथाको पृष्ठभूमि र परिचय}

कथाकार इस्मालीको बाटो कथा २०४२ सालमा पहिलो पटक वेदना साहित्यिक पत्रिकामा छापिएको थियो। पछि, यो २०६४ मा प्रकाशित कथासड्ग्रह काट् जर्किन डीमा सड्कलित रहेको छ, भने यस कथा सड्ग्रहका प्राय: कथाहरूमा विशेषत: नेपालको तराई क्षेत्रका वर्गीय जनजीवनका विषयवस्तुलाई समेटिएको छ। त्यसैले नेपाली मूलधारका कथाहरूभन्दा इस्मालीका कथाले भिन्न परिवेशको यथार्थताको प्रकटीकरणका साथै प्रगतिवादी चेतना एवम् समसामयिकता बोकेको छन्। कथाकार स्वयम् पनि तराई क्षेत्रको प्रतिनिधित्व भएका हुनाले यस बाटो कथामा त्यहीको स्थानीय भौगोलिक परिवेश एवम् ग्रामीण जनजीवनका सामाजिक सांस्कृतिक चित्रण जीवन्त पाइन्छन् । कथाकारले प्रत्यक्ष अनुभूत गरेका तराई क्षेत्रका विपन्न कथित दलित समुदायको जीवनका कथाव्यथाको अभिव्यक्ति भएका कारणले पनि यस कथाको महत्त्व विशेष देखिन्छ। सामन्ती संस्कृतिको सामाजिक आर्थिक शोषणमा बंधुवा मजदुर बनेका मुसहर बस्तीका मानिसहरूमाथि उक्त समाजका शासक ठालू वर्गको दमनकारी प्रभुत्वको अवस्था एकातिर चर्को देखिन्छ भने अर्कातिर त्यसका विरूद्धमा दमित वर्गमा देखिन थालेको चेतनाका भिल्कोलाई बढाएर मसालको रूप दिंदै बाटो देखाउने चेतनामूलक शक्तिको खोजीका प्रतीकात्मक अर्थमा कथा सबल रहेको छ।

बाटो कथा तराईको एउटा मुसहर बस्तीको जमिन्दारी संरचनाको सामाजिक सांस्कृतिक विषयबस्तुमा संरचित छ। मधेसको भू-स्थानिक परिवेश तथा वि.सं. २०४६ को जनआन्दोलनबाट स्थापित प्रजातन्त्र अघि र पछिको सङ्क्रमणकालीन समय परिवेशमा सत्तामा होडबाजी गर्ने राजनीतिक सन्दर्भको यथार्थ चित्रण प्रतिबिम्बित छ। अघिल्लो व्यवस्थाबाट वर्षोंदेखि गरिब, निमुखा वर्गमाथि एकलौटी हैकम चलाइरहेका तिनै मानिस फेरि परिवर्तित व्यवस्थामा पनि सर्वेसर्वा भई जनतामाथि उसैगरी हालीमुहाली चलाउने व्यवस्था फेरिए पनि प्रवृत्ति उही रहनु विडम्बनापूर्ण यथार्थ हो । कथाको प्रमुख पात्र सुरथ सदा विपन्न मुसहर समुदायको प्रतिनिधित्व गर्ने मजदुर हो । उसले पुस्तोंदेखि जन्मजात गाउँका प्रभुत्वशाली सामन्त ठूलो मालिक र सानो मालिकजस्ता ठालुहरूको चाकरीमा सधैं शोषित, निरीह भएर विपन्न आश्रित बँधुवा जीवन गुजार्न विवशछ। गाउँका शक्तिसाली सामन्तवर्गका व्यक्ति ठूलो मालिकको निधनपछि, उनको छोरो सानो मालिक र महेसर सिंह (मालिक)ले पालो गर्दे जनतामाथि शासनसत्ताको हैकम चलाउन अनेक षड्यत्त्रका दाउपेचबाट कहिले प्रतिद्न्द्री अलग पार्टी बनाएर फुटेका अनि फेरि आपसमा जुटेको रहस्य बुभ्न नसकेर सोको व्यक्ति सुरथ आश्चर्यचकित हुन्छ। उनीहरूजस्ता सोकासिधा गरिब निमुखामाथि अनेकौं राजनीतिक दाउपेच र जालभेल गरी आपसमा फुटाएर शासन गर्ने रणनीति मालिक वर्गको देखिन्छ। न्यूनतम आधारभूत जनजीविकाका स्रोत साधनबाट वज्चित रही आजीवन मालिकका बँधुवा दास बन्न विवश मजदुर समुदायलाई चेतना छर्दे ककभकाउने गाउँको मास्टर रामसोगारथ कोइरीलाई गरिबको खुन पसिना चुस्न पल्केको मालिकले आ0 नो बाटोको अवरोध ठानेको छ। एकदिन बिहानै मास्टर बाँसभ्याङमा मृत फेला पई तर हत्याको घटनाको खासै जाँचपड्ताल नगरी लास लगेर गएको पुलिसको हवल्दारसंग ठूलो मालिकको खुसामदले घटनालाई त्यत्तिकै सामसुम दबाइन्छ। अघिल्लै दिनदेखि नचिनेका जुँगे मान्छेहरू मालिको घरमा आवतजावत देखेको सुरथले पुलिसलाई बताए पनि सबैका सामु कबोल गर्ने हिम्मत नहुँदा हत्याको घटना सेलाउँछ। यो उदीयमान प्रतिरोधी विचारलाई निभाउने कुत्सित प्रयत्नको उदाहण पनि हो भने मास्टरको मृत्युसंगै एउटा सचेत पुस्ताको अन्त्य भए पनि चेतनाको भिल्कोलाई अर्को युवा चेथरुलालले निभ्न दिएको छैन। ठूलो मालिकको मृत्युपछि, सामन्ती सत्ताको बागडोर सम्हालेको सानो मालिकले फुट र जुटको नीतिबाट आ 0 नो 
स्वार्थअनुकूल राजनीतिक हत्कण्डा र दाउपेचद्वारा गाउँलेमाथि शासन गरिरहन्छ। मालिकले गरिबहरूलाई जसका विरूद्ध लडाएर आपसी दुश्मनी तथा अड्गभङ्ग बनाइ बेहाल पारेको छ, आफ्नो स्वार्थको निम्ति उसैसँग मितेरी लाएको छ। यसरी पालैपालो गाउँलेमाथि हालीमुहाली कायम राख्ने प्रवृत्तिले आन्दोलन र सत्ता परिवर्तनबाट केवल शासक/पात्र फेरिए पनि निरड्कुश दमनकारी शासकीय चरित्र/प्रवृत्ति नफेरिनाले सुरथ मुसहरजस्ता बहुसड्ख्यक निम्नवर्गीय श्रमजीवी सीमान्तीय वर्गका अवस्थामा यसले कुनै पनि उल्लेखनीय परिवर्तन आउन सकेको देखिन्न । यस्तो अवस्था विगतदेखि वर्तमानसम्मको नेपाली समाजमा निरन्तर देखिइरहेको समाजसंस्कृति वा राजनीतिक बिडम्बना पनि हो।

\section{पात्रको प्रतिनिधित्व र पहिचानको अवस्था}

प्रस्तुत कथा बाटोमा पात्रहरूको प्रतिनिधित्व र पहिचानको अवस्थालाई सामाजिक सांस्कृतिक संरचनाका आधारमा विश्लेषण गरिन्छ। तराईको भौगोलिक परिवेशका अभिजात्य र गैरअभिजात्य, सम्पन्न र विपन्न, जमिनदार/मालिक र मजदुर, सीमान्तीय र गैरसीमान्तीय, प्रभुत्वशाली र शक्तिहीन, शोषक र शोषितको तहगत विभेदकारी सामाजिक संरचना रहेको छ। परम्परावादी/यथास्थितिवादी तथा उदीयमान/प्रतिरोधी वर्गका पात्रहरू तथा विचारका माध्यमबाट सामाजिक सांस्कृतिक पक्षको उद्घाटन भएको पाइन्छ। यसअनुसार बाटो कथालाई अध्ययन गर्दा यी तिनै किसिमका प्रतिनिधित्वको प्रयोग भएको पाइने भएकाले यसमा प्रयुक्त पात्रहरू, उनीहरूबीचका संवाद, क्रियाकलाप, अभिप्राय तथा विभिन्न अवधारणा र सड्केतका कोणबाट हेर्न सकिन्छ। सामाजिक सांस्कृतिक संरचनाका घटक अवयवहरूका बारेमा विभिन्न मतअभिमतहरू विद्यमान छन् । स्टुआर्ट हलका अनुसार प्रतिनिधित्व पनि प्रतिबिम्बात्मक, अभिप्रायमूलक र संरचनात्मक स्वरूपको हुन्छ भने समाजको सांस्कृतिक संरचनामा विमर्शले दिएको पहिचान र सामाजिक नियमनका आधारमा व्यक्तिको प्रतिनिधित्वको अवस्था निर्धारण हुन्छ। प्रतिनिधित्वको सम्बन्ध समाजको उत्पादन र उपभोग प्रक्रियासँग पनि रहेको हुन्छ भनेका छन्। बाटो कथामा सामाजिक संरचनाले निर्धारित गरेका विभिन्न किसिमका वर्गीय पात्रहरूको प्रयोग रहेको छ। मालिक र मजदुर, उच्च र निम्न विपरीत वर्गका प्रतिनिधित्व तथा शक्तिसम्बन्धका आधारमा बाटो कथामा प्रयुक्त चरित्रका विश्लेषण गर्दा असन्तुलित किसिमको देखिन्छ। यसमा प्रतिनिधित्व गराइएका पात्रले एकातिर समाजमा हालीमुहाली गर्ने पुरानो सत्ताको दमनकारी विभेदपूर्ण चरित्रकै प्रधान्यता छ भने अर्कोतर्फ त्यसबाट उन्मुक्तिको चाहना राख्ने उदीयमान नयाँ पुस्ता पनि देखिंदैछन्। यी दुवैबीचमा विचारधारात्मक अन्तर रहेको छ भने सत्ताशक्तिका खेलाडी सानो मालिक र सिंह मालिकबीच प्रतिप्रभुत्वको सम्भावना पनि प्रवल देखिन्छ।

तराईका स्थानीय विभिन्न समुदायका प्रतिनिधित्व गर्ने समाजका विभिन्न पात्रहरूको प्रयोग भएको बाटो कथामा सम्पन्न र विपन्न दुवै वर्गका पात्रहरू छन् साथै तिनीहरू वर्गीय,जातीय र लिड्गीय प्रतिनिधित्वका दृष्टिले पनि फरकफरक छन् । ती पात्रहरूको माध्यमबाट उनीहरूबीचमा रहेको वर्गीय सम्बन्ध तथा सत्ता सम्बन्धको अभिप्रायलाई बुभ्न सकिन्छ।

\section{मालिक वर्ग}

तराई भेगका ग्रामीण समाजका पात्रहरू सामाजिक, आर्थिक शक्तिले सम्भ्रान्त ठूलो मालिक, सानो मालिक र सिंह मालिक(महेसर सिंह)आदि यसमा शक्तिसम्पन्न अभिजात वर्गको प्रतिबिम्बात्मक प्रतिनिधि हुन् । उनीहरूले समाजमा जहिले पनि सत्ताको नजिक रहेर शक्तिका आडमा तल्लो सीमान्तकृत समुदाय/गाउँलेहरूमाथि शक्तिशाली, वर्चस्वकारी 
भूमिकामा आफूलाई उभ्याएका छन्। यी व्यक्ति स्वयम्मा शोषक सामन्ती, दमनकारी चरित्रका छन् किनभने उनीहरू गरिबलाई गुलाम बनाउने, आ 0 नो व्यक्तिगत तथा वर्गगत स्वार्थ पूरा गर्न आपसमै लडाउने भिडाउने र आफ्ना विरूद्धमा आवाज उठाउनेलाई भौतिक रूपमै सिध्याउने कुर शासक पनि छन् । राजनीतिलाई माध्यम बनाएर त्यसको आडमा निकृष्ट जुनसुकै हदसम्म जान सक्दछ् र जनतामा भ्रमपूर्ण विचार छर्न सफल रहन्छन् भन्ने उनीहरूका मास्टरप्रतिको निदर्यी क्रियाकलापले प्रष्ट पारेको छ। कहिले एकअर्कासँग मिलेर गाउँलेमाथि पालैपालो शासन गर्ने ठूलो मालिक, सानो मालिक र सिंह मालिक (महेसर सिंह) स्वार्थ नमिल्दा फुटेर सोकासिधा तिनै गाउँले जनतालाई आपसमा भिडाएर एकअर्काका कट्टर दुश्मन बनाई आफू सत्ताको फाइदा लिइरहन्छन्। मालिक वर्गका वर्गीय स्वार्थ र चरित्र समान खालको रहेकाले जसरी भए पनि शासनत्तामा प्रभुत्व जमाउने र सत्ताका प्रतिनिधि बनेर गरिब निमुखामाथि उत्पीडक तथा दमनकारी बनेर हैकम चलाउने अभिप्राय रहेको छ। ग्राम्सीले भनेभैं यिनीहरूले सबैलाई शक्तिको कानुन प्रयोग तथा अन्य सांस्कृतिक साधनद्वारा अधीनस्थ बनाइएको हुनाले मालिकका हुकुममा प्राय: सबैको सहमति देखिन्छ :

सानो मालिक र सिंह मालिकको मितेरी फेरि कायम भएको उपलक्ष्यमा भोलि गाउँमा धुमधाम र भब्य भोज हुँदै थियो। इलाकाका ठूलाबडा र भद्रभलादमी भनिएकाहरूको जमघट हुँदै थियो। मालिकका घरमा खुसी फर्किएको थियो। गाउँलेहरू पनि खुसी थिए- कोही कोहीबाहेक। (पृ. 9)

यहाँ उल्लेख गरिएका 'ठूलाबडा र भद्रभलादमी' ले समाजका वर्चस्वशाली वर्ग वा प्रभुत्ववादी शक्तिका समर्थक तथा 'कोहीकोहीं शब्दले मालिकका पक्षमा नलाग्ने वा तिनीहरूका क्रियाकलाप मन नपराउने विरोधी पक्षको प्रतिरोधी शक्तिको पहिचान सङ्केत गरिएको छ। त्यस्तै मालिक र मजदुर सामाजिक संरचनाका विपरीत वर्ग तथा शक्तिसम्बन्धका प्रतीक हुन् जसले शासक र शासित, दमक र दमित, शोषक र शोषित तथा पीडक र पीडितको प्रतिनिधित्वको पहिचान स्थापित गरेका छन्। कथामा समाजका सीमान्तीय वर्गमाथि हरेक तबरले शक्तिशाली वर्गको अभिजातीय वर्चस्वको अवस्था तीव्र देखिन्छ।

\section{मजदुर वर्ग}

सुरथ सदा(मुसहर) र उसकी पत्नी औरहीवाली, जग्गुलाल, उसकी दुलही, भिखवा दुसाध आदि गरिब, मजदुर, नोकर, उत्पीडित, दमित, सीमान्तकृत पात्र हुन् । सामाजिक संरचनात्मक व्यवस्थाका निम्न वर्गको प्रतिनिधित्व गर्ने यिनीहरू सधैं गरिबीले सताइएर उनीहरूको पुस्तौपुस्ताको जिन्दगी पहिचानविहीन भई मालिक वर्गको गुलामीमै बितेको छ, जसलाई उनीहरूले आ0 नो नियति मानेर स्वीकारेका छन्। मालिकहरूले राजनीतिको आडमा सत्तामाथि आधिपत्य कायम राख्न निम्न वर्गीय मजदुरलाई प्रयोगका वस्तु बनाएका छन् । अर्को पार्टीविरूद्ध कैकगडा र सांघातिक युद्ध गर्न सिधासोका सर्वसाधारणलाई उक्साउने र पुलिस प्रशासनको शक्तिद्वारा फेरि तिनै गरिबलाई दमन गरी स्वार्थसिद्ध गई्छन् तर ज्यानको बाजी लगाएर लड्नेहरूको दुर्दशा कथामा साना मालिक र सिंह मालिकका पार्टीबीचमा भएको कगडाको प्रसड्गमार्फत प्रस्तुत अभिव्यक्तिले छर्लड़ पारेको छ : मालिकका लागि भिखवाले आफ्नो हात गुमायो, श्रीसम्पत्ति गुमायो 1 हातै नभएपछि के बाँकी रह्यो र कमाइ खानेका लागि $(\mathcal{Y})$ । यसले वर्गीय चरित्रका भिन्नतालाई सटीक ढड्गले देखाएको जुन हरेक समयसान्दर्भिक यथार्थ पनि हो । उपल्लो वर्ग बुद्धि र विवेकको प्रयोगले केवल आ0 नो फाइदामात्र 
हेछ तर तल्लो वर्ग अर्काको विचारबाट निर्देशित मुढे बल र नि:शर्त भावनाले अरूका लागि चल्ने हुनाले प्रभुत्ववादी शासकीय विचारधारालाई सधै सहयोग पुगेको हुन्छ।

\section{सत्ताको वर्चस्व र शक्तिसम्बन्ध}

सामाजिक सत्तासम्बन्ध र शक्तिको वर्चस्वले पनि प्रतिनिधित्व र पहिचानमा महत्त्वपूर्ण भूमिका खेलेको हुन्छ। यस बाटो कथामा प्रयुक्त मालिक-मजदुर, धनी-गरिब, उच्च-निम्न, गुलामी -आजादी जस्ता विपर्यास शब्दले बहन गर्ने अर्थमा नै विभेदक सत्ता र शक्तिको सामर्थ्य निहित रहेको पाइन्छ। प्रभुत्वशाली वर्गले उत्पादन गरेको अर्थलाई सीमान्तीय वर्गमाथि सत्ताशक्तिको चरम दुरूपयोग गरी जबरजस्ती हैकम चलाउने, लदाउने/दबाउने प्रवृत्ति नेपालको अन्यत्रभन्दा तराई क्षेत्रमा अभ तीव्र रहेको ज्वलन्त उदाहरण बाटो कथामा प्रस्तुत सत्ताको वर्चस्व र वर्गीय शक्तिसम्बन्धबाट देखिएको छ।

प्रस्तुत बाटो कथामा चित्रित कथित उच्च वर्गीय पुरुष पात्रहरू र निम्न वर्गीय पात्रहरूका बीचमा मालिक र मजदुरका रूपमा विपरित वर्गीय सत्तासम्बन्ध रहेको छ। मालिक वर्ग सदैव वर्चस्वकारी देखिन्छ भने लिड्गीय दृष्टिले यस कथामा प्रयुक्त पात्रगत तथा प्रवृत्तिगत प्रतिनिधित्वबाट पनि नेतृत्व परम्परागत पितृसत्तात्मक संरचनाका पुरुषसत्ता नै केन्द्रमा शक्तिशाली छ।

प्रस्तुत कथामा प्रतिनिधित्व, पहिचान तथा कार्यका दृष्टिले तराईको समाजमा महिलालाई सहायक, न्यून र कमजोर ठान्ने प्रवृत्तिको चित्रण रहेको छ। उनीहरू पहिचानविहीन भूमिकाका रहेका साथै सीमान्तकृत गरिएको उदाहरण मास्टर्नी, औरहीवाली, जग्गुलालकी पत्नी र चुल्हाईकी दुलही जस्ता नारी पात्र हुन् जसको आ0 नो नाम र पहिचानसमेत छैन। तिनीहरूलाई कि त जन्मस्थानका आधारमा चिनाउने औरहीवाली या लोग्नेका पहिचानबाट मास्टर्नी, जग्गुलालकी पत्नी, चुल्हाइकी दुलही आदिले सम्बोधन गरिएको छ। पितृसत्ताले नारीलाई केवल शारीरिक उपभोगको साधनमात्र मान्ने प्रवृत्तिको प्रतिनिधित्व उनीहरूप्रति प्रयोग गरिने भाषाका माध्यमबाट प्रकट हुने अर्थले जनाउँछ। हलको यस मान्यतानुसार यहाँ केटीलाई मालिकका मनोरज्जनका साधन भोग्य वस्तुका रूपमा चित्रित गर्ने शब्द 'छोकरी' पितृसत्तात्मक व्यवस्थाको लैड्डिक विभेदको प्रष्ट सड्केत हो। त्यस्तै अर्की नारी सामन्तवादी सत्ताले लोग्नेको हत्या गरी बिधवा पारिएकी मास्टर्नी वर्गीय विभेदविरूद्ध वर्ग एकता र सड्घर्षको पक्षमा अडिग रहने सचेत पात्रको प्रतिनिधि पनि हो । यस ‘बाटो’ कथामा प्रस्तुत सत्ताशक्ति र पहुँचका दृष्टिले अत्यन्त निरीह जातीय रूपमा उत्पीडित मुसहर वर्गको प्रतिनिधित्व रहेको पाइन्छ। यससंगै कथित तल्लो जातको मुसहर समुदायमाथि सत्ता, शक्ति र प्रभुत्वका दृष्टिले कथित उपल्लो मानिने शासकवर्गका ठूलो मालिक, सानो मालिक र सिंह मालिक(महेसर सिंह) आदिको बाहुबल र पुलिस प्रशासनको आडमा शासकीय हैकम चलिआएको छ :शक्तिका केन्द्र पुलिस प्रशासन पनि कहिले महेसर सिंहको पक्षमा लाग्यो त कहिले सानो मालिककोमा (६)। सर्वसाधारण सधैं शासित वर्ग भएकाले यसरी सिड्गो पुलिस प्रशासन नै मालिक वर्गका हातका कठपुतली बनेपछि जनता दोहोरो सत्ताको चेपुवामा फसेका हुन्छन्।

कथामा बिस्तारै वर्गीय अन्तरविरोध बढ़दै जान थालेको सङ्केत मास्टर रामसोगारथले बुद्धि र बल आजादीमा खर्चिनु पछ भनेबाट थाहा हुन्छ। उसले सुरथ, चोथरूलाल लगायतका मजदुरहरू वर्गलाई मालिकको गुलामीको जन्जीर तोडेर आजादीको स्वाभिमानमा बाँच्नुपछ र पछिल्लो पुस्तालाई स्वतन्त्रताको पारिलो चेतनामा उन्मुक्त बनाउनु पई 
भनी वर्गीय चेतना जागृत गराएको कुरा शासकसत्ताका पहरेदार मुखियाले मन नपराउनुबाट पुष्टि भएको छ। तत्कालीन नेपालको सड्क्रमणकालीन समाजमा अघिल्लो एकदलीय शासन व्यवस्थाको धङ्घड़ी बोकेर बहुदलीय व्यवस्थामा प्रवेश गरेका कतिपय शासकीय प्रतिनिधिहरूका चरित्र कथाका मालिक पात्रहरूमा दुरूस्तै भेटिन्छ। सांस्कृतिक निरन्तरताका रूपमा विकसित यस्ता चरित्रका विरोधी विचारसँग प्रतिवाद गर्न डराउनेहरूले त्यसलाई दबाउन भौतिक रूपमै मास्टरलाई समाप्त पार्ने प्रवृत्तिले तल्लो वर्गको प्रतिरोधी सत्ता पनि उत्तिकै शक्तिशाली भएर उदाउन सक्छ भन्ने अर्थ दिन्छ। निरड़कुश समाजव्यवस्थाको प्रतिनिधि माथिल्लो वर्ग अत्यन्त स्वार्थी, कुर, अनुदार तथा असहिष्णु र अलोकतात्त्रिक पनि रहेको अर्थ ठूलो मालिकले सुरथसँग मास्टर रामसोगारथको बारेमा गरेको संवादबाट प्रष्टिन्छ :

नयाँ टोलको कोइरी मास्टर छ, नि...त्यो मेलापर्म नि जान्छ रे हैन, गोठालो नि जान्छ रे हैन ? मालिक मजुर एउटै हुन् पनि भन्छ रे हैन ? त्यसको काम मास्टरी गर्नु कि गाउँले भाँड्नु ? पक्कै पनि नक्सलाइट होला... ठीक गर्नुपई । (पृ. २)

उपर्युक्त अभिव्यक्तिमा समाजका प्रभुत्वशाली वर्गका प्रतिनिधि ठूलो मालिक सदैब सर्वसाधारणलाई बँधुवा मजदुर बनाएर आफ्नो हैकम कायम राख्न चाहान्छ। गाउँलेमा स्वाभिमान, वर्गीय स्वतन्त्रता एवम् चेतनाको ज्योति जगाउन खोज्ने मास्टर सत्ताधारीको आँखाको कसिड्गर वा राजनीतिको वर्गीय शत्रु मानिनु स्वाभाविक हो र उसमाथि निगरानी तथा खतराको सङ्केत माथिको सङ्कथनमा भेटिन्छ। तर त्यो उच्च हैकमवादी सत्ताले यस्तो दमनकारी विचारधारा निर्माण गरेर समाजमा लागू गरी आधिपत्य जमाएको छ कि त्यसैलाई सहज स्वीकार्दे अशिक्षित अधीनस्थ निम्नवर्ग पनि मालिकका बोलीमा लोली मिलाउँदै समर्थन गर्ने संस्कृतिको उदाहरण सुरथको यस अभिव्यक्तिले प्रष्ट्याउँछ :

त्यतिमात्र कहाँ हो र मालिक ! बटदारहरूलाई जमिन जोत्नेको हुनुपछ, बेठबेगार गर्न पाइँदैन भन्छ, मजुरी बढाउनु पई्छ भन्छ। हजुर मालिक र मजुर कहीं एउटै हुन सक्छ र ? मालिक भन्या मालिक हो, मजुर भन्या मजुर हो ।...कस्तो उट्पट्याझ् कुरो गई, हजुर । ...-प्. .

संरचनावादी मार्क्सवादी चिन्तक अल्थुसरले विचारधारा विषयमा आधारित हुने र यस्तो विषयलाई सड्कथनले प्रभाव पार्ने हुन्छ (वार्कर, २००० : पृ. प६६) भनेकैं 'बाटो' कथाको उपर्युक्त संवादमा उनीहरूबीच प्रयोग भएको भाषिक व्यवहारबाट दमनकारी शासक मालिक वर्गले आ0 नो एकाधिकार रहेको ठान्ने सत्तासँग सम्बन्धित परिवर्तनको पक्षमा धावा बोल्दे दमित, शोषित वर्गको चेतना जागृत गराउने रामसोगारथको कार्यलाई महाअपराधकै दृष्टिले हेछ र ठीक पार्ने धम्की मात्र होइन, हत्या गरिदिंदा पनि कुनै विरोधको आवाज नउठ्नुमा भने त्यसमा नियन्त्रित वर्गको पनि निरीहता / सहमति रहेको कल्को पाइन्छ।

\section{प्रतिनिधित्व र ज्ञानको उत्पादन}

सांस्कृतिक अध्ययनले पाठमा प्रयुक्त विषय, पात्र, घटना, परिवेश, भाषिक सङ्कथन, सत्ताशक्ति, विचारधारा, प्रतिनिधित्व, पहिचान तथा अन्य विविध माध्यमबाट सांस्कृतिक अर्थ/ज्ञानको उत्पादन कसरी भएको हुन्छ भन्ने बारेमा पनि खोज विश्लेषण गर्दछ। स्टुआर्ट हलल त्यो तलबाट सिर्जित हुन्छ। प्रस्तुत बाटो कथामा तराईको अशिक्षित तर बहुसांस्कृतिक 
ग्रामीण परिवेशका अभिजात्य वर्चस्वशाली प्रतिनिधित्व र पहिचानका सन्दर्भमा प्रयुक्त भाषिक विमर्शले अर्थको उत्पादन गर्ने बताउँछन् भने मिसेल फुकोका अनुसार सड्कथनको तात्पर्य सामाजिक सन्दर्भमा अर्थको उत्पादन र संयोजन नै हो । ज्ञानको उत्पादन माथिको सत्ता र शक्तिबाट नभई जमिन्दार, उच्च वर्गीय, जातीय अहम् बोकेका एकल पुरुष लिड्गीय पात्रमार्फत अल्पसड्ख्यक वर्गले बहुसड्ख्यकको प्रतिनिधित्व गर्ने समुदायमाथि सामाजिक, राजनीतिक, सांस्कृतिक अधीनस्थता कायम गरिएको छ। सत्ता कब्जा गर्ने घृणित खेलमा संलग्न गराइएका लाटासुधा जनताहरू मालिकहरू किन फुटे ? गाउँलेहरूमाथि आ $\underline{\text { नो }}$ हैकम चलाउन तर हामी किन फुटयौ ? (६) भन्ने बुभ्ने प्रयत्नमा अलिकति भए पनि चनाखो र सरिक हुँदैछन् । जुट्नु र फुट्नुको स्वार्थी फोहारी राजनीतिक दाउपेचका खेलौना गोटी बनाइएका सर्वसाधारण समाजमा विभाजित हुँदा मालिकजस्तो निर्लज्ज भएर फेरि आपसमा मिल्न कठिन अवस्था पुग्नु तिनै मालिकका लागि खेल्ने फाइदाजनक अवसर हुन्छ। यसबारेमा सुरथ सदामार्फत अभिव्यक्त विचार मननीय देखिन्छ :

मालिकहरू के मतलबले फुटे र के मतलबले जुटे ? हामी मजदुरहरू के मतलबले फुट्यौ र के मतलबले जुट्ने ? मालिक फुट्ने, जुटे जुट्ने ? मालिकका लागि फुटिदिने, मालिकका लागि जुटिदिने ? मजदुर भन्या मालिकका खेलौना हुन् र ? हाम्रो आ0 नो कुनै अस्तित्व छैन ?(६)

उपर्युक्त कथनले दमित निम्न वर्गीय अस्तित्वको चेतनाको आवाज बोलेको छ। मालिकका अधीनबाट स्वतन्त्र भई जिउने चाहनाको प्रतिनिधित्व उसको उपर्युक्त कथनमार्फत अभिव्यक्त भएको छ। कथामा प्रयुक्त 'वाँसभ्याइ्ग' 'शरीरको निकास थुपार्ने, विरोधीलाई सफाया गरी फाल्ने ठाउँ, 'माटोको हाँडी' पुरातन सामन्ती विचारको प्रतिनिधित्व गर्ने कमजोर भाँडोको प्रतीकात्मक रूप, बिहानको उज्यालो' नवचेतनाको आशाजस्ता बिम्बात्मक प्रयोगबाट स्थानिक सांस्कृतिक परिवेशलाई पनि सड्केतित गरिएको छ। सुरथ सदाको मानसिक छटपटी, डर र अन्यौलता दर्साउने सड्केत कथनले सबथोक ठिकै थियो तर पनि उसको आँखामा निन्द्रा थिएन। धरिधरि लघुशड्का लागेजस्तो हुन्थ्यो (प्. २) अमानवीय उत्पीडनमा बाँच्नुपर्दाको मानिसमा देखिने मानसिक सङ्घातको चित्रण गरेको छ। उसको मानसिकतामा चलिरहेको अन्तर्दून्दू र आउने उज्यालो समयको आशावादी सड्केत यस भनाइले अभिव्यक्त गर्दछ, :

आकाश छुन लम्केका बाँसका टुप्पाहरूको बीचबाट कमशः एउटा आकृतिले रूप लिंदै गरेको देख्छ ऊ। त्यस रूपभित्र कलकलाउँदो भरभराउँदोहँसिलो एउटा अनुहार भुल्किन्छ के छ सुरथ ? भन्दै जान्छ (ऐ.)।अचेल ऊ पनि सोच्न थालेको छ : मालिकको दोस्ती त फर्केर आयो, के हाम्रो कटुता हराउँछ र ? भिखवाको काटेको हात फिर्ता पाउँछ ? चुल्हाइको दुलहीमा लागेको दाग पखालिन्छ ? सोच्छ सुरथ सदा, मालिकहरू किन फुटे ? गाउँलेहरूमा हैकम चलाउन, हामी किन फुट्यौं ?(७)

ज्ञानको उत्पादन र ग्रहणमा प्रभुत्ववादीके एकाधिकार रहेको र सीमान्तीयहरूको भूमिका दयनीय भए पनि यस कथाले उनीहरूलाई केन्द्रमा स्थापित गर्नुपर्ने विचार राखेको छ। यसमा प्रतिनिधित्व गर्ने विभिन्न वर्गीय पात्रले प्रभुत्वकारी, भवितामुखी र उदीयमान चेतनाको पहिचान दिएका छन् ।

\section{प्रतिरोधी चेतना}


साहित्यमा प्रतिनिधित्व गर्ने पात्रका क्रियाकलाप, विचार आदिले उसको पहिचान निर्धारित हुन्छ। त्यसैले बाटो कथामा पनि यिनै विभिन्न आधारमा पात्रहरूका पहिचान सड्केतित छन् भन्ने माथि उल्लेख भइसकेको छ। विचार वा चेतनाका दृष्टिले प्रभुत्ववादी वर्गका प्रतिनिधि मालिकहरूका ज्यादतीका विरूद्धमा आवाज उठाउने पात्र रामसोगारथ कोइरी जो निम्न समुदायको मास्टर, शिक्षित र वर्गीय चेतना भएको व्यक्ति जो जैविक बुद्धिजीवीको प्रतिनिधित्व हो । सामन्ती संस्कृतिका पहरेदार जन्मजात रूपमा समाजका कथित मालिक कहलाइएका अभिजात वर्गका सेवामा बँधुवा मजदुर बनी पुस्तौंपुस्ता बिताउन विवश विपन्न समुदायका मानिसलाई आo नो स्वअस्तित्वको पहिचान गराउँदै गुलामीबाट आजादीतिर डोयाउने चेतना जागृत गराउने ऊ मालिक वर्गको आँखाको तारो बनेको र षड्यन्त्रपूर्वक हत्या गरिएको व्यक्ति हो । कथामा ऊ एक जैविक बुद्धिजीवीका भूमिकामा रहेको देखिन्छ जसले मजदुर तथा निम्न वर्गमा प्रतिरोधी भावना र अर्थ निर्माण गर्न चेतना बिजारोपण गरी केही हदसम्म सफल पनि बनेको छ। तर उसको मृत्युसँगै प्रतिरोधी चरित्रको एउटा पुस्ता अस्ताए पनि उसको विचारको किल्कोलाई निभ्न नदिने मास्टर्नी पात्र पनि जीवित छ। उसको विचारबाट "मालिकमालिक एक हुन सक्छन् भने हामी मजदुर मजदुर एक हुन किन सक्दैनौं ? मालिकमालिकको पार्टी हुन सक्छ भने हामी मजदुरमजदुरको पार्टी किन हुन सक्दैन"'(६) मजदुरवर्गीय विश्वदृष्टि र वर्ग सड्घर्षीय विश्वदृष्टि प्रस्तुत भएको छ। रामसोगारथको हत्यापछि उसको परिवर्तनकामी विचारलाई संवहन गर्ने युवा पात्र चेथरुलाल कर्ण हो । मालिकका सम्पूर्ण जालभेल र किंगे दाउसँग परिचित उसको विचारमा जनता अशिक्षित असचेत हुँदा आ0 नो स्वार्थका लागि फुटेर र जुटैरै भएपनि शासन गई्छन् शासकहरू। आगामी पुस्ताको आशाको दियो चेथरुलालले भनेकैं जनता जागृत हुन थालेको खण्डमा मालिकहरू एक्लाएक्लै शासन गर्ने बल नपुगी उनीहरू एकजुट भएर शासन गई्छन् भन्ने उदाहरण : "अव उनीहरू एक्लाएक्लैको बल नपुग्ने भो अनि एकजुट भए, हामीमाथि शासन गर्न, हाम्रो भाग लुटेर खान’'(७)। यस्तो प्रवृत्तिका विरूद्ध प्रतिकारी शक्तिको उदयको आशा र अपरिहार्यता कथाको मूल सारवस्तु पनि हो । यसले शासकीय हैकमवादी ज्यादतीका विरोधमा उत्पीडित वर्गको बुलन्द प्रतिरोधी चेतना जागृतिको आवश्यकता देखाएको छ।

\section{लेखकीय विचारको प्रतिनिधित्व}

कथाकार इस्माली प्रगतिवादी चेतनाका सशक्त लेखक भएका कारण पनि उनको लेखकीय विचार कथामा प्रतिबिम्बित भएको छ। निम्न शोषित उत्पीडित वर्गप्रतिको संवेदनालाई उनले कथामा विभिन्न रूपमा प्रस्तुत गरेका छन्। लेखकीय विचारधाराको संवाहक पात्र मास्टर रामसोगारथ कोइरी शासक वर्गसँग प्रतिरोधी भावना राख्ने भएका कारण उसको क्रुरतापूर्वक हत्या गरिन्छ तर उसको प्रतिरोधी चेतनाको आवाज जीवितै रहन्छ। समाजका शोषित उत्पीडित वर्गको एकता र आजादीको चेतनालाई जनसमुदायमा फैल्याई उज्यालो भविष्यको चाहना राख्ने मास्टर रामसोगारथ कोइरीको वर्गीय चेतनालाई उसकी पत्नी मास्टर्नी लगायत निम्न वर्गीय मजदुर युवा चेथरुलाल कर्णले यथावत् राखेकाले आशावादी ज्ञानको अर्थ सन्चरणका साथै मजदुरवर्गीय विश्वदृष्टि र वर्ग सड्घर्षको आवश्यकताको उदात्तीकरण लेखकीय विश्वदृष्टिका रूपमा प्रस्तुत भएको छ।

\section{निष्कर्ष}


कथाकार इस्मालीको प्रस्तुत बाटो कथाले आधुनिक नेपाली कथाको समसामयिक धारमा नवीन शिल्पशैलीको प्रगतिवादी चेतनाको प्रतिनिधित्व गरेको छ। समकालीन समयको नेपाली तराई क्षेत्रको भौगोलिक स्थानिक परिवेशमा सामन्ती जमिन्दारी प्रथाका अवशेषहरूलाई सामाजिक, राजनीतिक तथा सांस्कृतिक सन्दर्भका माध्यमबाट सत्तासंरचना र शक्तिसम्बन्धका स्वरूपसँगै विकसित परिवर्तनकारी चेतना उजागर गरिएको छ। सांस्कृतिक अध्ययनका आधारमा यस कथाले सत्ताको वर्चस्वमा वर्गीय प्रतिनिधित्व र पहिचानका मुद्दालाई दरिलोसँग उठान गरेको छ। त्यसैले यसमा यथास्थितिवादी पुरातन संस्कृतिको उच्च वर्गीय दमनकारी हैकमवादी प्रवृत्तिको भण्डाफोर गर्दे त्यसको अन्त्यका लागि मजदुर वर्गीय एकता र प्रतिरोधी चेतनाका साथै वर्गसड्घर्षको अपरिहार्यतालाई प्रस्तुत गरिएको देखिन्छ। मजदुर सुरथ र चेथरुलालका संवादका माध्यमबाट उदीयमान चेतनाको सङ्केत गरिएका साक्ष्यहरूले प्रभुत्वशाली शक्तिलाई चुनौती थप्द्ध प्रतिरोधी चेतनाको उद्घोष गरेका छन्। परिवर्तनका लागि वर्गीय एकता र वर्गसड्घर्षको निरन्तरताबाट बिहानीको उज्यालोले अग्रगामी विचारको निर्देश गरेकैं यस कथाले परिवर्तनका चेतनामूलक अर्थको अभिव्यक्ति प्रतिनिधित्वका माध्यमबाट दिएको छ। बाटो कथाले सङ्क्रमणकालीन समाज तथा तत्कालीन कालखण्डको घटना र विविध चरित्रका प्रतिनिधित्व र पहिचानको प्रभावकारी प्रस्तुतिसँगै भविष्यको परिवर्तनकारी प्रगतिशील बाटोको खोजीमा अग्रसर रहेको छ। समग्रमा यस कथाले विद्यमान सामाजिक, सांस्कृतिक सन्दर्भमा तराई क्षेत्रको वर्गीय, जातीय, लैड्गिक तथा अन्य विविध समस्याको प्रतिनिधित्व र पहिचान गर्नुका साथै दून्द्वात्मक सामाजिक संरचनामा मजदुर वर्गीय विश्वदृष्टि प्रस्तुत गरेको निष्कर्ष रहेको छ।

\section{सन्दर्भसामग्री}

इस्माली,(२०६ ४), बाटो, काट् जर्किन डी, : साभा प्रकाशन ।

गिरी, अमर,(२०७०), सांस्कृतिक अध्ययनका सैद्धान्तिक अवधारणा, भृकुटी सांस्कृतिक अध्ययन विशेषाङ्क, भृकुटी,

एकेडेमिक पब्लिकेसन्स, पृ.११- ४६।

चैतन्य, (२०७०), समकालीन बुर्जुवा दर्शन र सांस्कृतिक अध्ययन, भृकुटी सांस्कृतिक अध्ययन विशेषाङ्क, भृकुटी

एकेडेमिक पब्लिकेसन्स, पृ. ३१४- ३२४ ।

बराल, ऋषिराज,(२०७३), मार्क्सवाद र सवाल्टर्न स्टडिज, साका प्रकाशन ।

भट्टराई, रमेशप्रसाद, (२०७०), सांस्कृतिक अध्ययनका मूलभूत सिद्धान्तहरू, भृकुटी एकेडेमिक पब्लिकेसन्स,

पृ. ३३४- ३६४।

शर्मा, मोहनराज, (२०४६), कथाको विकास प्रक्रिया (तेस्रो संस्करण),साका प्रकाशन ।

शर्मा, मोहनराज (२०७०), अवरजन अध्ययन र साहित्य, भृकुटी सांस्कृतिक अध्ययन विशेषाङ्क, भृकुटी एकेडेमिक पब्लिकेसन्स, पृ. ३१४- ३२प ।

सुवेदी, राजेन्द्र, २०७३, सांस्कृतिक अध्ययन र नेपाली साहित्य, पाठ्य सामग्री प्रकाशन ।

Barkar, Chris. (2000), Caltural studies: Theory and Practice: London, Thousand Oaks and Sage Publication. 